\section{A view of women in painting from the past to the present: the image of women in art and women painters}

Geçmişten günümüze resim sanatında kadına bakış: Sanatta kadin imgesi ve kadin ressamlar

\author{
Zühal Köse ${ }^{1}$ \\ Gülsün Şahan ${ }^{2}$
}

\begin{abstract}
The woman, has been one of the main themes of art throughout all art processes. Social processes and the place of women in society were also reflected in art and shaped the image of women in art. The same, artwork sheds light on the social conditions of the period. The fact that women remain in the background in social life is seen in the art of painting as in many other fields since the transition to the patriarchal order. Although the image of the woman has changed over the years, the woman is outside of her identity; It continued to be processed as a mother, wife or sexual object. Despite many advances in the individual works of contemporary artists and in the art that values women, a prejudiced view towards women has not yet been prevented. When the number of women engaged in art increases, women's selfexpression has brought a different dimension to this commodification instead of the male gaze. The inclusion of feminist discourse and the changing structure of the world in art has also affected the role of women in social life. Art is one of the methods that can be used to achieve social change. For this reason, it can be said that women should continue to raise their voices for
\end{abstract}

Özet

Kadın, tarih boyunca sanatın ana temalarından biri olmuştur. Toplumsal süreçler ve kadının toplumdaki yeri sanata da yansımış, sanatta kadın imgesini şekillendirmiştir. Aynı şekilde bir sanat eseri, dönemin toplumsal şartlarına da $1 s ̧ 1 \mathrm{k}$ tutmaktadır. Kadının toplumsal hayatta ikinci planda kalması, ataerkil düzene geçişten günümüze değin birçok alanda olduğu gibi resim sanatında da görülmektedir. Kadın imgesi, yıllar içinde değişime uğrasa da kadın kendi kimliği dışında; anne, eş veya cinsel bir obje olarak işlenmeye devam edilmiştir. Çağdaş sanatçıların bireysel çalışmalarına, sanatta kadına değer veren birçok ilerlemeye rağmen kadına karşı ön yargılı bakışın önüne geçilememiştir. Sanatla uğraşan kadın sayısı artıkça erkek bakışı yerine kadının kendini ifade etmesi bu metalaştırmaya farklı bir boyut kazandırmıştır. Feminist söylemin ve dünyanın değişen yapısının sanatta yer bulması kadinın toplumsal hayattaki rolünü de etkilemiştir. Sanat, toplumsal değişimi sağlamak için kullanılabilecek yöntemlerden biridir. $\mathrm{Bu}$ sebeple kadinlarin sanat yoluyla hak ve hürriyetleri uğruna seslerini yükseltmeye devam etmeleri gerektiği söylenebilir. Bu hususta en büyük rollerden biri kadın sanatçılara

\footnotetext{
1 M.A., National Ministry of Education, zhlkose@gmail.com (iD) Orcid ID: 0000-0002-3458-9875

2 Assoc. Prof. Dr., Bartın University, Faculty of Education, Lifelong Learning and Adult Education, gsahan@bartin.edu.tr (iD) Orcid ID: 0000-0002-1215-9727
} 
Köse, Z., \& Şahan, G. (2021). Geçmişten günümüze resim sanatında kadına bakış: Sanatta kadın imgesi ve kadın ressamlar. Journal of Human Sciences, 18(3), 431-449. doi:10.14687/jhs.v18i3.6151

their rights and freedoms through art. One of the biggest roles in this regard falls to female artists. In this research; Throughout history, the image of women in painting and women painters have been examined, and the process of women's existence in art has been evaluated. For this purpose, written documents on the image of women, women painters and their lives from past to present have been examined. The image of women in art and its change throughout history, prominent female painters in the world, the image of women in Turkish painting and Turkish women painters, have revealed the place of women in the field of painting.

Levina Teerlinc, Artemisia Gentileschi, Rosa Bonheur, Käthe Kollwitz, Frida Kahlo, Jeny Saville, Mihri Müşfik, Fahrünnisa Zeid, Şükriye Dikmen, Neşe Erdok, Nur Koçak and Gülsün Karamustafa, among the prominent painters in terms of Turkish and world history, were discussed.

Keywords: Art, woman image, woman painter, Turkish woman painter, patriarchal structure.

(Extended English summary is at the end of this document) düşmektedir.

$\mathrm{Bu}$ araştırmada; tarih boyunca resim sanatındaki kadın imgesi ve kadın ressamlar incelenerek, kadinın sanatta var olma süreci değerlendirilmiştir. $\mathrm{Bu}$ amaçla geçmişten günümüze kadın imgesi, kadın ressamlar ve hayatlarına ilişkin yazılı dokümanlar incelenmiştir. Sanatta kadın imgesi ve tarih boyunca değişimi, dünyada öne çıkan kadın ressamlar, Türk resim sanatında kadın imgesi ve Türk kadın ressamlar başlikları altında kadının resim alanındaki yeri ortaya koyulmuştur.

Türk ve dünya tarihi açısından öne çıkan ressamlardan Levina Teerlinc, Artemisia Gentileschi, Rosa Bonheur, Käthe Kollwitz, Frida Kahlo, Jeny Saville, Mihri Müşfik, Fahrünnisa Zeid, Şükriye Dikmen, Neşe Erdok, Nur Koçak ve Gülsün Karamustafa ele alınmıştır.

Anahtar Kelimeler: Resim sanat, kadın imgesi, kadın ressam, Türk kadın ressam, ataerkil yapı.

\section{Giriş}

Kadınlar tarih boyunca ataerkil yapı nedeniyle birçok alanda geri kalmıştır. Sanat da kadınların görsel olarak kullanıldığı, sanatçı olarak yer bulamadığı alanlardan birisidir. Küçükyıldız (2020: 11)'a göre sanat, bir duygu veya düşüncenin çeşitli yöntemlerde dişavurumudur. Kişinin yaratıcılığının, kabiliyetinin, hayal gücünün resim, heykel, müzik, tiyatro ve edebiyat gibi farklı sanat etkinlikleri yoluyla şekillenmesidir. İnsanın varoluşuyla başlayan estetiğin ve güzelliğin kurumsal bilimidir (İbrahimgil, 2015: 10). Bu nedenle sanatta kadına bakmak adeta insanlık tarihini ele almaktur. Kadının toplumsal hayattaki yerini anlamak da bize çok önemli ipuçları verecektir. Kadın, dünya tarihi boyunca farklı düşünce, toplumsal yaşam ve inanç nedeniyle bazen baş üstünde tutulmuş; lakin çoğu zaman yan veya ikincil insan olarak ele alınmıştır. Her toplumun kadına bakışını etkileyen önemli nedenler bulunmaktadır: Kimi zaman örf, adet, gelenek; kimi zamansa din veya inanç farklı davranışlara maruz kalınmasına sebep olmuştur (Azertürk, Akman, 2018: 1-2). Sanat tarihi düşünüldüğ̈̈nde, kadınların sanatta hep var olduğunu görmek mümkündür. Fakat kadın, erkeğin yansıttı̆̆ kadarıyla ve görsel tema ya da nesne olarak temsile dayalı bir rolle yer almıştır. Bu yok sayılmanın temel sebepleri; kadın erkek eşitsizliği, kadına toplumsal olarak biçilen roller, dönemin sosyo-ekonomik, kültürel ve siyasi şartlarıdır (Demirtaş Ercan, 2019: 2-4).

Kadının kendini birey olarak var etmeye çalıştığı alanlar arasında sanat da yer almaktadır. 19. yy'da gerçekleşen Feminist hareketle birlikte kadının var olma süreci ve hak arayışı sanat alanında da etkisini göstermiştir. Sanatta Feminizm ise 1960'lı yılların sonlarında geçmişten günümüze devam eden eril üstünlüğe başkaldırı olarak; erkeklerle eşit haklara sahip olma, kadın 
Köse, Z., \& Şahan, G. (2021). Geçmişten günümüze resim sanatında kadına bakış: Sanatta kadın imgesi ve kadın ressamlar. Journal of Human Sciences, 18(3), 431-449. doi:10.14687/jhs.v18i3.6151

haklarının korunmasına ilişkin kaygıları sanatla yansıtma sürecini kapsar. Feminizm; cinsiyetçi ayrıma dikkat çekerek bedenin bir seyir aracı olarak veya nesnel bir obje olarak sunulmasının normalleştirilmesini yanlışlığını ortaya koymuştur (Parten Altuncu, 2020: 144). Eril bakışın sanat yapıtlarında kadın vücudunu bir arzu nesnesi olarak sınırlandırılmasına karşı çıkan feminist akım; sanat oluşumunda alışılagelmiş ölçütlerin kadını sadece anne ya da eş gibi toplumsal rollere büründügünde yüceltildiğini ortaya koyarak, sadece kadının ve ona olan bakışın yüceltilmesi gerektiğini vurgulamaktadır (Krom, 2010: 126). Feminizm, önceleri toplumdan dişlanan, ötekileştirilen kadının sanat ve toplum için verdiği mücadele sürecinin aydınlık tarafıdır. Bu anlamda şekillenen sanat algısı aydınlığı simgelemiş birçok kadına ve kadın sanatçıya öncü olmuştur (Gücer, 2020: 10).

$\mathrm{Bu}$ araştırmanın amacı resim sanatında kadın imgesinin tarih boyunca değişimine bakmak, dünyada ve Türkiye'de öne çıkan kadın ressamlar aracilı̆ı̆la resim sanatında kadının var olma sürecini incelemektir. Sanat eserleri ve sanatçılar, dönemin yaşam tarzını ve dünyaya bakış açısını yansıtmaktadırlar. Bu nedenle toplumdan doğrudan veya dolaylı olarak etkiledikleri ve toplumu etkiledikleri söylenebilir. Kadının toplumsal hayatta yalnızca kadın kimliğiyle var olma sürecini, sanatla ilişkilendirmek mümkündür. Sanatta kadının durduğu noktayı ve kadın ressamların verdiği mücadeleyi gözler önüne sermenin, tarih boyunca kadınların eşit haklar uğruna verdiği mücadeleye destek sağlayacağı düşünülmektedir. Bu sebeple toplumun kadına bakışında bütüncül bir değişim oluşturmak için sanat eserlerinde kadın imgesinin nasıl yansıtıldığı göz ardı edilmemelidir. Literatür incelendiğinde resim sanatında kadın imgesinin değişimini yansıtan sınırlı sayıda araştırmaya rastlanmıştır. Bu yönüyle araştırmanın, kadının sanatta var olma sürecini bütüncül bir yapıyla anlatması hususunda önem arz ettiği düşünülmektedir.

\section{Yöntem}

Sanatta kadın imgesini inceleyen bu makalenin temel amacı kadının sanatta var olma sürecini anlatmaktır. Bu amaç doğrultusunda alanyazın taranarak geçmisten günümüze kadın imgesinin Türk ve dünya tarihi açısından değişimi ve dünyada ve Türkiye'de öne çıkan kadın ressamlara yönelik araşturmalar incelenmiştir. Bu amaca uygun olarak tarama modeli yöntem olarak belirlenmiştir.

Tarama araştırmalarında, bireylerin ya da nesnelerin doğrudan kendisinin incelenebildiği gibi önceden kaydedilmiş çeşitli kayttlara(resimler, yazılı belge, istatistikler, görüntü ve ses kayıtları) alandaki kaynak kişilere ve eski verilere başvurarak, elde dilen dağınık verileri, araştırmacı kendi gözlemleriyle birleştirip bir sistem içerisinde bütünleştirerek yorumlayabilir (Karasar, 2016). Tarama makalelerinde araştırmacı daha önce basılmış olan materyali tamamlayarak, düzenleyerek ve değerlendirerek bir problemi açıklama yoluna giderek bu bağlamda var olan araştırma sürecini biçimlendirir ( Büyüköztürk ve diğ., 2021). Bu araştırmada tarama modeline uygun olarak veri tabanları (EBSCO, ERIC, Google Scholar, TR Dizin, Dergipark ve Yök Tez) kullanılarak araştırma amacina hizmet eden dokümanlar taranmıs, elde edilen bilgiler sistematik bir şekilde incelenerek araştırmanın amacı doğrultusunda sınırlandırılmış, düzenlenmiş ve yorumlanmıştır.

Yapılan literatür taraması sonucunda makalede yer alacak kadın ressamların sınırlandırılması yapılırken; resim alanında ilk adımları atan, eril düzene rağmen sanatla uğraşmayı bırakmayan, erkek egemen sanat camiasında kendini kanıtlamış, yeteneğiyle örnek teşkil eden, kadın hakları ve kadın erkek eşitliği hususunda çalışmalar yapan ve hayatı kadınların sanatla uğraştıkları süreçte karşılaştıkları zorlukları gözler önüne seren kadın ressamlar seçilmeye özen gösterilmiştir. Bu amaç çerçevesinde Levina Teerlinc, Artemisia Gentileschi, Rosa Bonheur, Käthe Kollwitz, Frida Kahlo, Jeny Saville, Mihri Müşfik, Fahrünnisa Zeid, Şükriye Dikmen, Neşe Erdok, Nur Koçak ve Gülsün Karamustafa'nın yaşam öyküsü kısaca anlatılmıştır.

Araştırmada resim sanatında kadın imgesi sırasıyla; sanatta kadın imgesi ve tarih boyunca değişimi, dünyada öne çıkan kadın ressamlar, Türk resim sanatında kadın ve Türk kadın ressamlar başlıkları altında ele alınacaktır. 
Köse, Z., \& Şahan, G. (2021). Geçmişten günümüze resim sanatında kadına bakış: Sanatta kadın imgesi ve kadın ressamlar. Journal of Human Sciences, 18(3), 431-449. doi:10.14687/jhs.v18i3.6151

\section{Sanatta Kadın İmgesi ve Tarih Boyunca Değişimi}

Birçok tanımı olan imge kavramı, duyu organları aracılı̆̆ıla algılanan şeyin somut veya hayali kopyası olarak tanımlanabilir. Sanatın ve sanat geçmişinin anlaşılması imgelerin çözülmesiyle mümkün olacaktır; çünkü sanat imgelerin temsilidir (Bayav, 2009: 106). Farklı sanat dallarında zihinsel olarak düşünülen şey veya şeyler gözle görülür bir imge haline getirilmektedir. Kadın imgesi mekânı, devri, zamanı ve toplumu yansıtan niteliğiyle karmaşık bir yapıdadır. Kadın bedeni ve imgesi kendi üstünde anlam bulan tüm değeriyle düşünülmeli ve yorumlanmalıdır (Kaya Okan, 2011: 5). Kadının varlığ1 ve önemi insanın varoluşundan beri her zaman ön plandadır. Dünya tarihi boyunca yaşayan toplumlar incelendiğinde her birinin kendi inancı veya anlayışına binaen kadını farklı konumlandırdığını görmek mümkündür. Kadın içine cin girmiş cadı, güzellik abidesi, tanrıça, mitolojik bir heykel gibi farklı şekillerde görülmüştür. Kadın her uygarlık ve toplum için önemli olsa da hak ettiği değer verilmemiş, ikinci sınıf insan muamelesi görerek itilip kakılmıştır (Gülaçtı, 2012: 89). Kadın bedenine bakış, tarih boyunca değişime uğrayarak sembolik bir anlama sahip olmuştur. Dönemin popüler olan ideal kadın imgesi resimler, heykeller ve mozaikler gibi birçok sanat eserine yansımıştır. İlham kaynağı olan kadın; inanç, kültür ve toplum yapısı doğrultusunda farklı şekillerde tasvir edilmiştir (Dağ, 2019: 17).

İlk Çăglarda Kadin Imgesi

Kadının imgesinin sanatta yer alma süreci paleolitik dönem değin uzanmaktadır. Mağara resimlerinde iki boyutlu olarak yansıtılan kadın imgesi aynı zamanda üç boyutlu heykelciklerle de simgelenmiştir (Yazgın, 2019: 187). Venüs heykelciği olarak adlandırılan paleolitik dönemde yapılmış kadın heykelciklerinde kadın bedenin göğüs, kalça ve cinsel organlarının abartılı biçimde işlenmiş büyüklüğü dikkat çekmektedir. Bu büyüklüğün sebebi bereketin sembolü olarak üremede büyük rol oynayan kadını kutsallaştırmak, doğum oranının artmasını sağlamaktır. Yani kadın imgesi doğurganlığı ve cinsel kimliğiyle öne çıkmaktadır (Kaplanoğlu, 2006: 6-7). Kadına verilen önem tarıma geçişle Neolitik çağda ilk etapta artmıştır. Bunun sebebi, toprağın ve kadının temel zenginlik kaynağı olduğu düşüncesi ve kadının doğurganlık rolüdür. Çünkü toprağın işlenmesi için daha fazla kişiye ihtiyaç vardır. İkisi de hayatı sağlıyor ve üretiyordu. Bununla birlikte kadının rolünün baskınlığının asıl sebebi kadının anneliği değil tarımda temel üretici konumda olmasıydı. Süreç içinde erkeklerin tarım tekniklerini öğrenmesiyle toplumsal statüler tamamen değişikliğe uğramıştır. Erkek kadını ikincil plana iterek evde ve toplumda temel üretici lider konumunu almıştır (Karaca, 2015: 4-7). Böylece anaerkil dönemin zamanla sona ermiştir. Bu durum neticesinde sanat eserlerindeki kadının etkin varlığı giderek silikleşmiştir.

\section{Antik. Misir'da Kadin Imgesi}

Antik Mısır'da kadının sahip olduğu hak ve hürriyetler, aynı dönemdeki diğer uygarlıklara oranla daha fazladır. Kadının sahip olduğu hakları kanunlar haline getiren dünya tarihinin ilk medeniyetidir. Kadını kutsal bir varlık olarak kabul eden Mısırlıların eserlerinde kadın ve erkeğin yan yana resmedilmesi toplumun kadına verdiği değeri ve kadın erkek eşitliğini simgeler niteliktedir (Babila, 2016: 140). Eski Mısır'da kimi zaman kadınların yönetimde etkili olduğunu görmek mümkündür. Antik Mısır’ın ilk kadın firavunu olan Hatşepsut'un M.Ö. 1503-M.Ö. 1445 y1lları arasında hüküm sürdüğü düşünülmektedir. Yılmaz (2020: 277) 'e göre Hatşepsut sanatsal çalışmalarda genellikle erkeklerin geçtiği bir makamda bulunması sebebiyle kendini kimi zaman bir erkek figürü olarak betimletmiştir. Bununla birlikte öz benliğini açığa çıkaran ve kadın kimliğini gizlemeyen eserler de yaptırmıştır. Resmî törenlerde bir firavun geleneği olan sakal takmayı ve iktidarda olduğu süre boyunca benzer seremonileri de yerine getirmiştir. Firavun eşlerinden biri olan Nefertiti (M.Ö 1379-1362) ve Misır'da bir dönem egemen olan VII. Kleopatra (M.Ö. 69-12) ise Misır sanatında yer alan önemli kadın figürlerindendir.

\section{Antik Yunan'da Kadın Imgesi}

Antik Yunan'da ise derin bir kadın düşmanlığı vardır. Kadın figürü, zayıflık-güçsüzlük fikriyle özdeşleşmiş, kötülükle ilişkilendirilmiş (Pandora), ilk günahı işleyen (lanetli Havva), günah faili olarak nitelendirilmiştir (Karaaslan, 2016: 161-162). Kadinlar erkekler tarafindan aşağılanmakta, hor görülmekte ve hakarete uğramaktadırlar (Güzel, 2015: 505). Yunan sanatında, 
Köse, Z., \& Şahan, G. (2021). Geçmişten günümüze resim sanatında kadına bakış: Sanatta kadın imgesi ve kadın ressamlar. Journal of Human Sciences, 18(3), 431-449. doi:10.14687/jhs.v18i3.6151

kadın çıplak olarak resmedilmiş, kadın deneyimiyle alaka kesilerek bereket ve doğumla ilgili kaynaklarından uzaklaşılıp, kadın imgesi ataerkil toplum için estetik ve ideal forma bürünüp erkek arzusunu yansıtan bir hal almışır (Özbay Aydoğan, 2006: 4). Heykeli yapılan bütün kadınlar güçlü ve sağlıklı görünüme sahiptir. Genellikle çıplak olarak sanatta yer alan kadın, idealize edilen kadın anlayışını yansıtmaktadır. Fiziksel güzellikle ahlak arasında mükemmelliğe dayalı bir ilişki kurulmuştur (Yanar, 2010: 12). Kadın ideal figüre uygun resmedildiğinden dolayı Antik Yunan resim sanatında; modelin normal yaşantısı ve görünümü anlaşılmamakla birlikte sanatsal bakış açısına dair bilgi edinmek mümkündür (Aktan, 2015: 54) Bu durumdan hareketle kadının toplumsal yaşantısı ile sanata yansıtılan yönü arasındaki farklılaşma sebebiyle metalaştırlılıarak cinsel bir obje olarak algılandığını söylemek mümkündür.

\section{Roma ve Orta Căg'da Kadin Imgesi}

Antik Roma döneminde ise kadın imgesi; kadının nesneleștirildiği, rızasının aranmadığı, erkek üstüncü bir bakışın olduğu, kadın bekâretinin idealleştirildiği, kadının iffetinin toplum tarafindan sorgulandığı bir konumdadır. Kadınların bazı temel haklarının olduğu, tam vatandaş sayılmadı̆̆1, dolayısıyla oy vermeleri ya da siyasette yer almalarının söz konusu olmadığ1 bilinmektedir (Söğütlü Erişgin, 2016: 1-26). Hiristiyanlık'ın yaygınlaşmasıyla, Geç Roma'dan Orta Çağ’a gelindiğinde, kadın imgesi rahibelere ve azizelere dönüşmüştür. Antik sanattaki güzelliğiyle ön plana çıkan çıplak vücutların üzeri örtülmüştür. Bundan böyle resim ve heykel sanatında tapılası ve hayranlık uyandırıcı kadın bedenin yerini mucizevi öykülerin şaşkınlığını yaşayan ve ibretlik hikayelerin hüznünü taşıyan yüzler ve bedenler almıştır (Karaca, 2015: 11-12). Orta Çă̆'da kadına yapılan eziyet ve dayak normal bir davranış sayılmış aynı zamanda Roma Katolik Kilisesi'nin kanunlanında da yer almıştır (Ghorbanzadeh Dizaji, 2013: 3). Kadın bakire, dul ya da evli şekilde sosyal konumlara ayrılmış, soylu sınıfa mensup olan kadınlar ise ayrı gruplandırllmıştır. Dönemin kadın anlayışı; ahlaki olarak kırılgan, fiziksel olarak zayıf, günahtan ihtiyatla sakınması gereken ve bir erkeğin korumasına muhtaç şeklindedir (Akkaya Kia, 2015:14). Kadın resimlerde, okuma yazma bilmeyen halka Hiristiyanlık'ı yayma maksadıyla Meryem figürü olarak ortaya çıkmaktadır (Dağ, 2019: 19).

\section{Rönesans'ta Kadin Imgesi}

Kesenci (2020: 31-46)' ye göre Rönesans Dönemi; birçok savaş ve hastalıkların olduğu, buna karşın sanatının yüceltildiği, zenginleştiği bir dönemdir. Kadınlar birçok alanda ikinci plandadır ve yine birçok haktan yoksundur. Rönesans'ta ideal sanatçı erkektir; fakat Rönesans'in sanata verdiği değer kadınlar için de bir ümit olmuş ve kadınlar gayri resmi olarak sanat eğitimleri almıslardır. Fakat kadınların erkeklere oranla daha fazla çaba sarf etmeleri gerekmiştir. Erkekler profesyonel eğitimler alırken kadınlar çoğu zaman babaları tarafindan yetiştirilmiştir. Bu nedenle ancak soylu ailelerin kızları genellikle resimle uğraşmışlardır. Kimi zaman eşlerinin ismiyle, kimi zaman anonim olarak resimler yapan kadınlar; zamanla kendi tekniklerini geliştirerek özgün çalışmalarla adlarını duyurmuş ve sanat camialarına kendilerini kabul ettirmişlerdir. Kendilerini yetiştiren ve sanat tarihinde yer almayı başarabilmiş birçok kadın sanatçının eserleri günümüze kadar ulaşabilmiştir. Rönesans’ta ideal kadın imgesi değişime uğrayarak Venüs adıyla, mitolojisiyle, ideal güzelliği ve çıplaklı̆̆ıyla geri dönmüştür. Rönesans sonrası serbestleşme sinırlı bir alanda kalmış; Rokoko ve Barok dönemde sanatta kadın imgesi kilisenin baskısıyla dini ya da mitolojik şekilde ele alınmıştır. 17. ve 18. yüzyılda dahi sanat alanında dinin etkisinin devam ettiğini söylemek mümkündür (Işıkören, 2015: 122).

\section{Fransiz Devrimi Sonrası Kadm Imgesi}

Fransız Devrimi, düşünen kadının kendini daha fazla göstermesini beraberinde getirmiştir. İhtilal sürecinde Rönesans’ta yarım kalan hürriyet ve eşitlik bu süreçte karşıllk bulmaya başlamıştır. Kadınlar; devrim sürecinde seslerini daha ziyade yükseltmiş, pasif kalmayarak etkin rol oynamışlardır. Bu süreç Sanayi Devrimi'nde de devam etmiştir (Akalın, Baş, 2018: 117). Fransız İhtilali sonrasında kadın figürü sadeleşmeye başlamış abartılı kadın imgelerinin yerini, sağlıklı kadın imgesi almıştır. Daha sonraki dönemde İkinci Dünya Savaşı'ndan sonra yuvarlak hatlara sahip balık etli kadınlar tercih edilerek sağlık ve güzellik sembolü 
Köse, Z., \& Şahan, G. (2021). Geçmişten günümüze resim sanatında kadına bakış: Sanatta kadın imgesi ve kadın ressamlar. Journal of Human Sciences, 18(3), 431-449. doi:10.14687/jhs.v18i3.6151

olmuşlardır. Televizyon ve sinemanın güç kazanması sonrasında ise idealize edilen kadın ekranlarda görülen özgür kadın olmuştur. Bronz tenli, güzel ve dolgun bedene sahip, burjuvaziden uzak imaj olarak daha özgür kadınlar önem kazanmıştır (Aydın, Karakelle, 2019: 478).

\section{Modern Toplumlarda Kadm Imgesi}

Sanayi Devrimi'yle başlayan işgücü ihtiyacı sebebiyle kadınların çalışma hayatına atılması, kadınların sosyal ve ekonomik açıdan bağımsızlıklarını elde etmeleri açısından önemli bir adım olmuştur. Kadın kimlikleri sebebiyle ezilen ve ötekileştirilen kadınların, bilinç düzeyi artıkça zamanla kitlesel bir harekete dönüşen hak arayışı süreci başlamışırı. Bu süreç feminist hareketin başlamasına öncülük etmiştir. Ressamları da etkileyen feminist düşünce, kadını sanatın ilgi odağına dönüştürmüştür (Satır, 2012: 4). Fransız ve Sanayi Devrimi sonrasından günümüze değin uzun süren mücadelelerden sonra kadınlar, insanlığın bilinçlenmesine ve gelişmesine katkı sağlayarak kendilerine daha medeni bir yer edinmişlerdir. Kadın imgesini hapsoldukları evlerden çıkarmış; umutsuz, boyun eğen, pasif kadını yürekli, hak ve hürriyetlerini savunan, eril toplumun sıkıştırdığı kalıbın dışında duran bireye dönüştürmüşlerdir (Uçar, 2020: 49-50). 19. yy. sanat ve kültür anlamında tarihsel süreçler itibariyle bir kırılma noktası olmuştur. Sanatçı; yeni temsil ve görme problemleri üzerine düşünen, etken, gözlemci, üreten ve öz benliğine dönmüş değişen realitenin sanatsal anlamdaki temsilcisi olmuştur. Modern sanatun birey ve objenin yer değiştirmesine imkân sağlayan bakış açısı, sanatçıların değişim sürecindeki gerçekliğin kadın imgesi üzerinden nasıl yansitıldığını gözler önüne sermiştir (Özensoy, 2017: 71). Yüzyıllar boyu resimlerde modellik yapan kadın 20. yüzyıla gelindiğinde artık sanat hayatındaki yerini ispatlamış, edilgen konumdan sıyrılarak yaptığı çalışmalarla başarısını kanıtlamıştır. Böylece modern toplumlarda kadın sanatta kadın olarak var olmaya başlamışır. Sanatta kadın imgesi; güzel vücutlar, günlük hayattaki işler veya anlamlı bakışlar yerine kadının gizemli iç dünyasına yönelmiştir. Sanatçıya göre kadın algıları farklılıklar göstererek bireyselleşmiş, sanatçının aynası olmuş, kimliğini yansıtır hale gelmiştir (Çelebi Kalpak, 2019: 20-21).

\section{Dünyada Öne Çıkan Kadın Ressamlar}

Resim eğitimi usta çırak ilişkisi ile başlamıştır. Çıraklık sisteminin resim sanatının eğitiminde etkili olduğu dönemlerde 15.yüzyıl sonlarına kadar bütün koşullar erkeklere uygun olarak hazırlanmıştır. Bu nedenle bu dönemlerde kadın çırağa dair bilgilere rastlanmamaktadır. Genel olarak sanatçı ailelerde yetişmiş veya üst sınıfa mensup kadınlar özel dersler aracıllğıyla eğitim alabilmişlerdir. Var olan ve daha sonraki süreçlerde artan akademilere kadınlar kabul edilmemiştir. Ë̆itimini ilerletmek, ressamlı̆̆ı meslek edinmek isteyen kadınlar genellikle bir usta ressamın atölyesinde eğitim görmüşlerdir. Kadınların akademilere kabulü 19. yüzyılın ortalarına rastlamaktadır. Kadın hakları hareketiyle birlikte erkeklerle eşit eğitim koşullarına kavuşmuşlardır. Eğitimin dışında tutuldukları süreçte dahi kadınlar önlerine koyulan engellere rağmen resim yapmayı bırakmayıp sergiler açmışlar, sanatı meslek olarak seçip uluslararası düzeyde başarılar kazanmışlardır (Keser, 2013: 79-83). 20. yüzyıla gelindiğinde çok büyük bir değişim gerçekleştirerek ressamların ilham kaynağı olan kadın, pasif konumdan aktif hale geçerek resmi yapan kişiye dönüşmüş; her alanda gösterdiği başarıyı resim alnında da sergilemiştir (i்ldeş, 1996: 20). Kadınlar yüzyıllar boyunca her alanda cinsiyet ayrımcıllğıyla mücadele etmişlerdir. Sanat da bu alanlardan biridir. Kadının kendini ispatlayabilmesi veya sanat çevrelerine katulabilmesi için erkek isimleriyle eserlerini yayınlaması, kadın olduğu için yaptığı eserlerin değer görmemesi, istediği şartlarda eğitim alamaması gibi birçok engelle karşılaşmıştır. Çalışmanın bu kısmında farklı ülkelerden başarılı kadın ressamlar kronolojik sırayla ele alınmıştır.

\section{Levina Teerlinc (1510- 1576)}

Belçika'da doğan sanatçı ünlü bir sanat geçmişine sahip olan ailenin beş kızının en büyügüdür. Minyatür sanatçısı olan babası tarafindan yetiştirilmiştir. İyi bir minyatürcü ve ressam olan Levina, insanların benzerlerini yapma konusunda çok yetenekliydi. İngiltere kralından iş teklifi alan sanatçı uzun yıllar ailesiyle birlikte İngiltere'de yaşadı. Kral VIII. Henry tarafindan kraliyet ressamı unvanı verilmiş ve tarihte bu unvanı alan ilk kadın olmuştur (Przybylek, 2021: 1). 
Köse, Z., \& Şahan, G. (2021). Geçmişten günümüze resim sanatında kadına bakış: Sanatta kadın imgesi ve kadın ressamlar. Journal of Human Sciences, 18(3), 431-449. doi:10.14687/jhs.v18i3.6151

Dönemin mahkeme ressamının ölümü üzerine yerine geçen Levina, 16. yüzyılda yaşayan erkek meslektaşlarından daha fazla ücret almasıyla dikkatleri üzerine toplamıştır (Kathleen, 2018:2). Sanatçının eserleri, meslek ve eğitim yaşamı ile ilgili az bilgi bulunmaktadır. Üslubu dikkate alınarak bazı eserler ona atfedilmiştir. Hakkında var olan bilgilerin büyük çoğunluğu babasının el yazması çalışmalarından elde edilmiştir. Sanatçı hakkındaki bilgilerin azlığı, bilgilerin çoğunluğunun babası tarafindan tutulmuş olması, kadınların tarih boyunca arka planda tutulmasının bir örneği olduğu söylenebilir (Kesenci, 2020: 33). Uzun süreler boyunca tanınmayan, hak ettiği değeri bulamayan, eserleri başkalarına atfedilen, sanat tarihi açısından önemi büyük olan sanatçı; çeşitli tarihçilerin yaşamını ve yapıtlarını incelemesiyle sanatının hak ettiği övgüleri yeni yeni almaktadır. Levina'ya atfedilen eserlerin artışıla ise sanatçının bilinirliği yaygınlaşmaktadır (Kathleen, 2018: 2).

\section{Artemisia Gentileschi (1593 - 1656)}

Roma'da doğan İtalyan barok ressamlarından biri olan Artemisia ilk eğitimini ressam olan babası tarafindan almıştır. Onun yeteneğini ilerletmesi için babasının işe aldığı ressam Agostino Tassi tarafindan tecavüze uğramıştır. Uzun ve sancılı süren dava sonunda Tassi suçlu bulunarak sekiz ay hapis yatmıştır. Artemisia'nın yaşadığı tecavüz olayı sanatçının itibarını zedelemiş ve Artemisia, iffetsiz bir kadın olduğuna dair dedikodulara maruz kalmıştır. Bu olaydan kısa bir süre sonra olayların kötü etkilerinden korumak maksadıyla babası bir evlilik ayarlamıştır. Evliliğinin ardından Floronsa'ya taşınan sanatçı, Floransa Güzel Sanatlar Akademisi’ne kabul edilen ilk kadın olmuştur. Evliliğinden kendi gibi ressam olan iki kız çocuğu dünyaya getiren sanatçı; bir müddet sonra eşinden ayrılmış, ömrünün sonuna kadar çağdaşlarının çoğundan farklı olarak özgür ve bağımsız yaşamış, 1641'de Napoli kentine taşınarak ömrünün geri kalanını orada tamamlamıştır (Mavioğlu, Karbeyaz, 2017: 141-144). 19 yaşında resmettiği en bilindik eserlerinden biri olan "Judith ve Holofernes" dikkatle incelendiğinde, yaşadığ1 travmaların, ruhsal çöküntünün etkisini görmek mümkündür. Dönemin savunmasız, çaresiz kadın anlayışının aksine güçlü ve kararlı bir kadın figürü resmetmiş, birçok ressam tarafindan işlenen bu konu en çarpıcı şekilde Artemisia tarafindan ele alınmıştır (Uyar, 2016: 15-16).

Ahlaksızlıkla suçlanan, çirkin sözlere maruz bırakılan, hayatı boyunca bu durumla mücadele eden sanatçı; gerek resimleriyle gerekse kadın hakları konusundaki uğraşı ile yaşadığı dönemde birçok şehirde tanınmıştır. Ancak ne yazık ki Artemisia, ölümünden sonra 1916'da yeniden keşfedilene kadar unutulmuştur (Salas, 2019: 130). Sanatçının yaşadığı bu durum, kadın sanatçıların başarılı olsalar dahi erkek egemenliğinin hüküm sürdüğ̈ bir alanda yüzyıllar sürecek bir unutuluşa kurban gidebileceklerinin göstergesidir. "Neden tarih boyunca başarılı kadın sayısı az?” sorusu akıllara geldiğinde Artemisia’nın yaşamı bütün cevapların özeti niteliğindedir.

Hakkındaki karalamalara rağmen Artemisia, sanatıyla ve cinsiyetler arası eşitlik için aralıksız mücadelesiyle zamanının en büyük kadın modeli ve cesaret örneği olmuştur. (Salas, 2019: 130). Bununla birlikte resimlerindeki başarısıyla dikkatleri üzerinde toplamış, yaşadığı ac1 dolu olayla ve ortaya koyduğu yapttlarıyla feminizmi sanatsal ve düşünsel olarak etkilemiştir. Sanatçı, feminist düşüncenin başyapıtlarından olan Judy Chicago'nun “Akşam Yemeği Partisi”" adlı eserine, birçok kitap, şiir ve filme konu olmuştur (Duran, 2018: 113).

\section{Rosa Bonheur (1822-1899)}

Rosa, dört çocuklu bir ailenin en büyük çocuğu olarak Fransa'da dünyaya gelmiştir. İlk eğitimini babasından alan sanatçı, on dört yaşına geldiğinde Louvre'da heykel ve resim eğitimi almıştır. Babası doğayı ve hayvanları resmetmesini teşvik etmiş, bunun için olanaklar sağlamaya çalışmışır. At fuarlarına giderek hayvanları daha iyi anlamak isteyen sanatçı, kadın olarak zorluk yaşadığından erkek kılı̆̆ına girerek çalışmalarını sürdürmüştür (Can, 2019: 399-400). Doğaya olan tutkusu ve yaptığı hayvan resimleriyle tanınan sanatçı aynı zamanda iyi bir heykeltıraştır. Daha sonra erkek kardeşinin ününü gölgelememek için heykel yapmayı bırakmışır. Feminist tarafinı gizlemeyen Rosa, kadınların yaptığ1 eserlerin erkeklerle yan yana sergilenmesine özen göstermekle beraber kadın ressam ve heykeltıraş grubunun başkanı olduğu süreçte bu tutumunu korumuştur. 
Köse, Z., \& Şahan, G. (2021). Geçmişten günümüze resim sanatında kadına bakış: Sanatta kadın imgesi ve kadın ressamlar. Journal of Human Sciences, 18(3), 431-449. doi:10.14687/jhs.v18i3.6151

Yaşamı boyunca hiç evlenmeyen sanatçı henüz otuz iki yaşındayken vefat etmiştir (Sağlam, 2000: 33-34).

Käthe Kollwitz (1867-1945)

Alman ressam, gravür sanatçısı ve heykeltıraş olan sanatçı, sanatı vasıtasıyla haksızlıklara ve savaşa karşı mücadele etmiştir. İlerici orta sınıf bir aileye mensup olan sanatçının avukat olduğu halde duvarcı ustalığ1 yapan babası, kızının resme olan yeteneğini fark etmiş ve özel dersler almasını sağlamıştır. Çeşitli okullarda da eğitim gören Kollwitz, dönemin ahlaki ve siyasi problemleriyle ilgilenmiş; bu nedenle Hitler'in gücünün artmasıyla 1933'te profesörlük yaptığ1 Prusya Güzel Sanatlar Akademisi'nden atılarak hayatının son yirmi y1lında yapitlarının sergilenmesine izin verilmemiştir (Fırınc1, 2006: 146). Erkeklerin çoğunlukta olduğu sanat alanında sesini duyurmayı ve kendini var etmeyi başaran sayılı kadın sanatçılardan biri olan Kollwitz'in eşi, sosyal demokratların üyesi bir doktordur ve bu evlilikten iki erkek çocuğu olmuştur. Gönüllü olarak katıldığı I. Dünya Savaşı sırasında yaşamını yitiren küçük oğlunun ölümü sanatçıyı derinden etkilemiştir. Sanatı toplumsal bir görev olarak düşünen sanatçı acı çeken anne ve çocukları, dönemim toplumsal koşullarını, sömürülen işçileri ve ezilmiş fakir insanları eserlerinde yansıtmıştır (Kaynar Tanır, 2019: 3-4). Kollwitz, bütün yaşamı boyunca kadın hakları ve işçi sınıfin hakları için mücadele etmeyi bırakmamıştır. Bu savaşçı ruhunu olgun bir sanatç1 duyarllığıyla birleştirerek eserlerine yansıtmıştır (Demirel, 2016: 143). Kadınların sosyal haklarını kazanması için mücadeleler veren Kollwitz, resimlerinde kadını sosyal düzene ve fakirliğe boyun eğmeyen, savaşan bir şekilde tasvir etmiştir. Anneliği eril düzenin negatif etkilerini ortadan kaldıran bir güç olarak gören sanatçı, anneliğin bir zayıflık olmadığını vurgulamaktadır. Sanatının büyük kısmını kadınların seslerini daha fazla duyurmalarını sağlamak amaciyla hak ve hürriyetleri talep etme, barışsever olma ve toplumsal değişimleri sağlama gibi hususlara ayırmıştır (Ayan, 2008: 46). Kollwitz'in eserleri, insanı derinden etkileyip rahatsızlık uyandıran imgelerle yüzleşmesini sağlayarak yaşanan tüm sıkıntıları ve çaresizlikle dolu zamanları benliğinde kendisi yaşanmışçasına hissetmesine yol açmaktadır. Sanatçının başarısı eserlerinde barınan tüm bu duygularda yatmaktadır (Şahinbaş ve diğ, 2019: 170).

\section{Frida Kahlo (1907 - 1954)}

Meksika'da dünyaya gelen Frida, devrimci yönüyle dikkat çeken bir ressamdır. Yaşamı süresince devrimi tutkuyla savunmuş, hatta bu tutkusu sebebiyle doğum tarihini Meksika Devrimi'nin tarihiyle değiştirmeyi istemiştir (Çokatak, 2014: 8). Babası iki evlilik yapmış olan Frida, dört kız kardeşi arasından tuhaf ve akıllı olarak görülmüştür. Yaşamının ilk yıllarında çocuk felci geçirmesiyle acıyla tanışmıştır. Babasıyla güçlü bir bağı olan Frida’nın fizik tedavisiyle ve aldığı eğitimle babası yakından ilgilenmiştir. On sekiz yaşında geçirdiği trafik kazasından sonra vücudunda birçok kemik kırılmıştır. Uzun bir dönem yatağa bağlı yaşayan sanatçı, türlü ameliyatlar geçirmiş ve yaşamı boyunca sürecek bir acıya mahkûm olmuştur (Demir, 2012: 3839). Diego ile yaşadığı inişli çıkışlı ilişki, sanatçının hayatında önemli yer tutmaktadır. Yaşamı boyunca üç kez hamile kalan Frida, sağlık problemleri nedeniyle çocuk sahibi olamamıştır. Resimlerinde de karşımıza çıkan bu durumdan derinden etkilenen sanatçı, anne yönünü desteklemek için birçok evcil hayvan beslemiştir. Sıkça bozulan sağllğına rağmen resim yapmaktan vazgeçmemiştir. Başarılı kariyerini devam ettirerek Amerika, Fransa, Meksika gibi çeşitli ülkelerde sergiler açmıştır. Otoportreleriyle tanınan Frida; feminist duruşuyla, devrim anlayışıyla ve cinselliğe bakışıyla birçok insanı ve sanatçıyı etkilemiştir (Yıldırım, 2010: 7-10). Boyayı, fırçayı, renkleri ve tuvali kendi iç devinimlerini ve yaşanmışlıklarını anlatma aracı olarak kullanmıştır (Dönmez Aydın, 2016: 36). Frida için resim yapmak, hastalıkla geçen yaşamından bir kurtuluş çaresi olmuştur. Acılar, sıkıntılar, sadakatsizlikler ve politik kaygılar içinde bir bölümünü yatağa bağlı geçirdiği hayatında sanatı vasıtasıyla 1zdıraplarını anlatmıştır. Bu yönüyle Frida Kahlo sanat tarihinde benzersiz bir simge haline gelmiştir (Kaptan, 2013: 70). 
Köse, Z., \& Şahan, G. (2021). Geçmişten günümüze resim sanatında kadına bakış: Sanatta kadın imgesi ve kadın ressamlar. Journal of Human Sciences, 18(3), 431-449. doi:10.14687/jhs.v18i3.6151

\section{Jenny Saville (1970-...)}

Yaşayan en önemli figüratif ressamlardan biri olan sanatçı, ressamlığın demode olarak algılandığı bir dönemde Cambridge'de dünyaya gelmiştir. Çağdaş sanatın en etkili örneklerini sergileyen sanatçı, sanata olan tutkusunu asla bırakmamıştır. Eserleriyle figüratif sanatın bittiği iddialarına son vererek bu alanda güçlü ve yenilikçi çalışmalar yapmıştır (Kurşunlu, 2019: 79). Amerika'da eğitim aldığı dönem, kadın figürüne bakışındaki kırılma noktalarından biri olmuştur. İnsan bedenine ilişkin çalışmalar yapmayı seven sanatçıyı kısa kıyafetler içinde gördüğü iri yapılı, beyaz tenli kadınlar fazlasıyla etkilemiştir (Renkçi, 2014: 138). Sanatçı, özneyi ve nesneyi altüst ederek resimsel mekânda arzu nesnesi olarak görülmek istenen kadın figürünü arzulara direnen yeni bir bedene bürüyerek resmetmiştir (Durmuşoğlu, 2004: 74). Young British Artists' üyesi olan Saville eserlerinde insan figürünü kendisini kabul etmiş, yabancılaşmadan uzak bir beden olarak ele alır; ama başka bir şeye dönüşme isteği duyan bir canlı olarak görür. Bedene bakışta insanın zarar görebildiğini, incinebildiğini duyumsatan sanatçı; genellikle şişman kadınları, estetik ameliyat geçirmiş insanları, komaya girmiş vücutları, kazada yaralanmış çocukları konu edinmekle beraber kendisini de model olarak kullanır (Albayrak, 2012: 7). Şişman bir kadın olmamasına karşın resimlerinde kendini obez bir insan olarak çizer ve eleştirel bir bakış açısıyla sunar. Devasa boyutlardaki ve mükemmel beden algısını sorgulayan eserlerinde en başta kadın üzerinde baskı oluşturan ve ona diretilen zayıf vücutların daha güzel ve çekici olduğu algısına karşı çıkmaktadır. (Akkan, 2014: 32-33). Sanatçı halen Londra ve Oxford'da resim çalışmalarına devam etmektedir (Renkçi, 2014: 138).

\section{Türk Resim Sanatında Kadın}

Türk tarihi boyunca bütün toplumsal yapılanmalarda, yerleşik yaşama geçişten Islamiyet’in kabulüne değin geçen süreçlerin tamamında var olan değişimlerin hepsi kadınların hayatını doğrudan etkilemiş ve dolayısıyla resim sanatında da değişimlere yol açmıştır (Küçükşen Öner, 2017: 105). İslami toplumlarda resim sanatının mümessili minyatür olmuştur (Sözer Sarac, 2011: 184). Osmanlı minyatürü eril söylemin hâkim olduğu toplumsal yapıyı destekler niteliktedir. Kadının toplumdaki yerini olumsuz etkileyen bu erkek egemen düşüncenin günümüzde dahi olumsuz etkileri devam etmektedir. Erken dönemde beden figürü, yüz betimlemeleri gibi hususlarda dinin etkisiyle yasaklar ve kısıtlamaların olduğu, kadın imgesinin de bu doğrultuda ele alındığ1 göze çarpmaktadır. Kadının erkekle birlikte tasvir edilmesi ancak tarihi el yazmalarının artışıyla mümkün olmuştur. Genel olarak minyatür hanedana yönelik yapılmakta ve kadın da minyatürde bu ilişkileri temsilen yer almaktadır. Batılılaşma süreci, minyatürdeki kadın imgesini de etkileyerek halk arasında ve arka planda resmedilen kadının ön planda resmedilmesine, peçeli ve kapalı kiyafetlerden sıyrilip daha cesur kiyafetlerle tasvirine sebebiyet vermiştir.(Gümüşer, 2013: 26). Batılllaşma süreciyle birlikte 19. yüzyılda batı resminin etkisinin artmasıyla minyatür yerini resim sanatına bırakmış ve yaygınlığ azalarak geleneksel sanatlar çatısı altında varlığını devam ettirmiştir (Sözer Sarac, 2011: 184). Batı sanatının etkisiyle kadın imgesi, Türk resminin başlıca konularından biri haline gelmiştir. Kadın imgesine dair değişimler, önce edebiyata daha sonrasında ise resme yansımıştır. Tanzimat'tan günümüze değin kadına ilişkin eserler incelendiğinde, Türk toplumsal hayatındaki farklılaşmanın resmindeki imgesel yansımalarını görmek kaçınılmaz olacaktır (Şahin, 2014: 1). Geç Dönem Osmanlı resimlerine bakıldığında, dönemin kadın figürünün yansımalarını görmek mümkündür. Geçmişte erkeğin gölgesinde bırakılan kadının konumu, Batı oryantalizminin Doğulu kadın anlayışına karşı çıkmak maksadıyla değişime uğramıştır. Resimlerdeki kadınlar genellikle üst zümrelere mensup kimselerdir. Ancak Sanayi Devrimi ve savaşların sonucu olarak çalışma hayatına katılan kadını ve kadın erkek eşitliğine dair bulguları dönemin resimlerinde görmek mümkün değildir (Erişti, 2015: 76).

Sanayi-i Nefise Mektebinin 1883'te açılması, resim sanatında kadın imgesinin dönüşüm sürecinin basamaklarından biri olmuştur. Önceleri minyatürde yer bulan kadın figürü, Batılı üslupta resim yapmaya geçiş sürecinde ortadan kaybolmuştur. Kadın imgesinin resim sanatına yeniden girmesi, Osman Hamdi Bey'in çalışmaları ve Sanayi-i Nefise Mektebinde verilen eğitimlerden sonra mümkün olmuştur. Kadın temsilinin resimde kaybolma süreci, toplumsal 
Köse, Z., \& Şahan, G. (2021). Geçmişten günümüze resim sanatında kadına bakış: Sanatta kadın imgesi ve kadın ressamlar. Journal of Human Sciences, 18(3), 431-449. doi:10.14687/jhs.v18i3.6151

yaşamda kadının uğradığı değişime bir işarettir. Çünkü kadın, iç mekanlardan çıkıp ev içi mahremiyet algısının dışına sıyrılmayı başarmış ve kısıtlamalardan kurtulmuştur. Bu durum, ilerleyen süreçler boyunca resim sanatında kadın imgesinin dönüşümünün başlangıcı olmuştur (Dastarl1, 2019: 78). Cumhuriyet'in ilanıyla birlikte resim estetik kaygilardan ziyade toplumu dönüştürmek, devlet politikalarına yönelik modern kadın kimliği oluşturmak için bir araç olarak kullanılmıştır. Resimlerde kadın, modern eş ve anne, kamusal alanda aktif imgeye dönüşmüş ve modernleşmenin simgesi haline gelmiştir. Tanzimat ve II. Meşrutiyet dönemlerinde peçe takmayan, piyano çalan ve dans eden yeni kadın imajı çizilmekle birlikte bu durum yalnızca tablolarda kalmış kamusal alana yansımamıştır. Cumhuriyet'le birlikte kadın kamusal alanda da yer bulmuş, kendi çıkarlarıyla birlikte toplumun çıkarlarını da gözetmesi beklenmiştir (Ergönül, Koca, 2017: 781). Toplumsal uyanış silsilesinde kadının günlük hayatı, var olma çabası, geleneksel değerleri, çağdaş kültüre uyum gibi süreçler empresyonizm (izlenimcilik) akımına göre resmedilmiştir (Şen, Gürpınar, 2019: 888). 1960 sonrasındaki özgürlükçü kadın politikalarının etkisi, kişi merkezli hayat tarzının yaygınlaşması gibi faktörler, resim sanatında normalleştirilerek ifade edilmiş olsa da süreç içinde farklılaşan düşünce yapısı ve yaygın kimlik politikalarının da etkisiyle kadın temsiline farklı bir boyut kazandırma uğraşı söz konusudur. Günümüze kadar olan zaman zarfinda kadın, bir taraftan kamusal ve özel alanda kabul görürken diğer taraftan kendini geleneksel düşünce yapıları ve kadını cinsel obje gibi sunan beden politikalarıyla karşı karşıya bulmuştur. Tüm bu hususlar, kadının eril söylem ve onun hayat yansımalarının bir parçası olmaktan bütünüyle sıyrılamadığının göstergesidir. Birçok sanatçı, günümüzde kadını bir nesne gibi gören bu bakışın ve ataerkil düzenin karşısında durarak kadın imgesini bu zihniyetlerin dışına taşımak maksadıyla eleştirel bir yaklaşım izlemektedir (Küçükşen Öner, 2017: 114).

\section{Türk Kadın Ressamlar}

Kadın sanatçı yetiştirme süreci ülkemizde 19. yüzylın yarısından sonra başlamıştır. Avrupa'daki gelişmelere oranla yüzyıllardır heykel ve resim yapmanın günah sayıldığ bir toplumda sanat alanındaki gelişmeler ancak Batıllaşma süreciyle ilerlemiştir. Eril bir yapıdan gelen Osmanlı Devleti'nde erkekler için sanat eğitimi okulu varken kadın ressamlara eğitim verebilecek bir okul mevcut değildi. Mihri Müşfik Hanım'ın öncülügünde yapılan çalışmalarla bu durum son bulmuş ve 1914'te kadınlar için İnas Sanayi-i Nefise Mektebi açılmıştır. Ülkemizin sanat tarihi açısından önemli bir yere sahip olan ve ilk kez kadın sanat eğitimi veren bu okul sayesinde birçok önemli kadın ressamın yetişmesi sağlanmıştır. Toplumumuzda kadının sanat eğitimi alma süreci bu tarihten itibaren başlamış; ancak kadınların eğitimci ve sanatçı kimliği Cumhuriyet'in ilanıyla birlikte şekillenmiştir (Dilmaç, 2011: 112-113). Türk kadın ressamların adları çağdaşlaşma sürecinden sonra ön plana çıkmaya başlamıştır. Bundan mütevellit kadın sanatçı kimliğinin, toplumsal düzen ve tarihi süreçlerin etkilendiğini söylemek kaçınılmazdır (Şahmaran Can, 2016: 1017). Bu nedenle Cumhuriyeti'nin ilanından sonraki süreçte kadın ve erkeklere eşit haklar tanınması, Türk kadınını her alanda güçlendirmiş; hukuki destekle birlikte kadınların resim sanatında ilerlemeleri de başarılarının artmasını sağlamıştır. Türk kadını, resim alanında gösterdiği başarıların yanında eril düzene ve sosyo-kültürel yapıya direnç göstermiş bunu da kazandıkları başarılarla gözler önüne sermiştir (Akçay, 2015: 5-20).

Çalışmanın bu kısmında Türk resim sanatında ilk adımları atan, kadın kimliğini destekleyen, toplumsal yapıya eleştirel bir üslupla yaklaşan, resim alanında kadının da var olabileceğini ispatlayan, sanatın cinsiyetle değil yetenekle ilişkili olduğunu gözler önüne seren, gelecek nesillere örnek teşkil eden kadınlardan bir kısmı ele alınmıştır. Seçim yaparken ressamların kadın konusuna duyarlı olmaları, yeteneğiyle sanat camiasında değer görmeleri, yenilikçi adımlar atmaktan çekinmemeleri ve kendine has bakış açılarıyla mesaj vermekten çekinmemeleri dikkate alınmışır. Sıralama yapılırken doğum yılları esas alınmıştır.

\section{Mihri Müşfik (Rasim) Hanım (1886-1954)}

Aydın ve kültürlü bir ailenin kızı olan Mihri Müşfik Hanım, İstanbul'da Rasim Paşa konağında doğmuştur. Sanatçının yeteneğini İtalyan ressam Fausto Zonaro keşfetmiştir. Ressamdan dersler alan Mihri Hanım kendini geliştirmek istemiş; fakat dönem itibariyle kadın 
Köse, Z., \& Şahan, G. (2021). Geçmişten günümüze resim sanatında kadına bakış: Sanatta kadın imgesi ve kadın ressamlar. Journal of Human Sciences, 18(3), 431-449. doi:10.14687/jhs.v18i3.6151

ressam yetiştiren bir okul bulunmadı̆̆ından Avrupa'ya kaçmıştır. Bu yönüyle resim eğitimini Avrupa'da alan ilk Türk kadın ressam olmuştur. Yurda döndükten sonra İnas Sanayi-i Nefise Mektebinin kurulumuna öncülük eden sanatçı, almış olduğu eğitimle birçok kadın ressam yetiştirmiştir (Eroğlu, 2017: 23-24). Tutku dolu ve cesur bir karaktere sahip olan sanatç1, Papa XV. Benedictus'un resmini yaparak Vatikan'a giren ilk kadın ressamdır. Üretkenliğiyle bilinen Mihri Hanım’ın, yaşamı boyunca farklı tekniklerle ve farklı konularda yaptı̆̆ 150 eseri kayıtlara geçmiştir. Ünlü simaların portrelerini yapan sanatçının resimlerindeki kadın imgesi ise karakterini yansıtır şekilde özgür, batılı ve moderndir (Sürücü, 2011: 18-25).

\section{Fahrelnisa Zeid (1901- 1991)}

Önemli Osmanlı ailelerinden birine mensup olan sanatçı İstanbul'da dünyaya gelmiştir. Seramik sanatçısı Füreya Koral'ın teyzesi olan sanatçı, aynı zamanda ressam Aliye Berger ve yazar Cevat Şakir Kabaağaçlı'nın kardeşidir. İlk evliliğinden dünyaya gelen tiyatrocu Şirin Devrim ve ressam Nejat Devrim'in annesidir. Sanatla iç içe bir çevrede büyüyen Fahrelnisa, ilk öğrenimini Inas Sanâyi-i Nefîse Mektebinde tamamlamış, daha sonrasında ise çeşitli ülkelerde eğitim hayatına devam etmiştir. Irak büyükelçisiyle evlenerek prenses unvanı almıs, eşinin işi ve bulunduğu konum sebebiyle birçok ülkeye seyahat etmiş ve farklı ülkelerde yaşamıştır. Bu sayede farklı sanat çevrelerini tanıma ve resimlerinin farklı ülkelerde sergileme imkânı bulmuştur (Güray, 2020: 48). Sanat kariyerine portre ve natürmort çalışmalarıyla başlayan sanatçı, daha sonra serbest firça darbelerinin ve lirik soyutlarının hâkim olduğu lirik soyutlamalara geçiş yapmıştır. Birçok Avrupa şehrinde sergi açan ressamın, müze ve koleksiyonlarda, yurt dışında ve ülkemizde dahil olmak üzere birçok eseri bulunmaktadır (Bayav, 2011: 22-23). Sanatçı için resim yapmak hayatının anlamıdı. Adeta resim yaparak nefes alıyor, büyük bir tutkuyla çalışmalarını icra ediyordu. Ölüme yaklaşıp doksan yaşına geldiğinde dahi bu süreç son bulmamıştı. Sürekli yeni arayışlar içinde olan Zeid; yetmiş beş yılllk resim hayatını hep sanatla doldurmuş, yetenekli gençlere resim dersi vermek hobisi haline gelmiş, Amman'da yaşadığı süre boyunca mutluluk kaynağına dönüşmüştü (Halman, 2011: 140).

\section{Şükriye Dikmen (1918-2000)}

İstanbul'da dünyaya gelen Dikmen, aile dostu Feyhaman Duran sayesinde sanatla tanıştı. İstanbul Güzel Sanatlar Akademisi Lisesinde eğitim alan sanatçı birçok önemli hocadan ders aldı. Resim hayatına kazandığı bursla birlikte Paris'te devam eden Dikmen, aynı zamanda sanat tarihi bölümünü bitirdi. Paris'te kişisel ilk resim sergisi açan sanatçı yabancı sanat eleştirmenlerinden beğeni topladı. Ülkeye döndükten sonra Ankara ve İstanbul'da sergiler açarak özgün tarzıyla takdir gördü (Akçaoğlu, 2010: 22-26). Çağdaş Türk Resim Sanatının önemli temsilcilerinden olan sanatçı, kadın imgesini yalın, kendine has yorumuyla ve çağdaş bir anlayışla ortaya koymuştur. Kullandığ1 renkler, malzemeler ve çeşitli teknikler özgün üslubunu destekler niteliktedir. Portrelerinin yanı sıra yaptığı manzara resimleri ve Türk motiflerini işleme tarzıyla dikkat çekerek soyut resme yeni bir bakış kazandırmıştır (Karabaş Avşar, 2016: 267).

Neş'e Erdok (1940-...)

İstanbul'da dünyaya gelen sanatçı “1960 Kuşağı” resim topluluğunun en önemli mümessillerindendir. Tekrarlardan uzak duran ve düşüncelerini kendine özgü tarzıyla tuvale yansıtan Erdok, figüratif resmin usta isimlerindendir. Figürlerini bilinçli bir sadelikle bazen deforme ederek bazı zamanlarda ise insan boyutunda çizmiş ve ruh hallerini mekanla ilişkilendirerek ele almıştır (Şentürk, 2018: 86). Mimar Sinan Üniversitesi Güzel Sanatlar Akademisinde atölyesi bulunan ilk profesör kadın ressam unvanına sahip olan sanatçı, toplumcu gerçekçi bir bakışla resmettiği kadın imgesini, topluma şekil veren aynı zamanda toplumun şekillendirdiği kadınları bir birey olarak resmeder. Gözler önüne serilen gerçekçilik duygusunun yaşantı ve içtenlikle harmanlanan içeriği yapttlarında orantılı bir yansımayla görülmektedir (Menteşeoğlu Chatzoudas, Günaydın: 338-399). Hayal gücünü izlenim, dönüştürme, alg1 ve gözlem becerileriyle bütünleştiren Erdok'un yarattığ1 yapıtları onun gerçeğinin ta kendisidir (İz, 2006: 109). Sanatçı toplumsal problemleri, etkilendiği durumları ve hatıralarını konu edinirken gözlemci kimliğini ön plana çıkarır. Toplumsal sorunlar tuvalinde yer bulurken seyircisine anlamlı 
Köse, Z., \& Şahan, G. (2021). Geçmişten günümüze resim sanatında kadına bakış: Sanatta kadın imgesi ve kadın ressamlar. Journal of Human Sciences, 18(3), 431-449. doi:10.14687/jhs.v18i3.6151

mesajlar vermektedir. Gözlemlediği ve etkilendiği halkı dengeli bir kompozisyonla sunar. Melankolik havayı yansıtan renkleriyle sanatçı üslubu ve tarzıyla özgünlügünü korur (Tiryaki, 2019: 87). Sanatçının eserlerinde amaç izleyici eğitmek değil, bakan kişiyi resmedilen konuya çekmektir. Bir iletişim aracı olarak kullandığı resimleriyle içsel hesaplaşmalar ve farkındalık oluşturma hedefini vurgular niteliktedir. Sanatçının üslubu kolay anlaş1lır ve durağan bir anlatım sergilerken bakan kişiye anlatılmak istenenin yoğunluğuyla bir çelişki yaşatmaktadır (Yılmaz, 2011: 171).

\section{Nur Koçak (1941-...)}

İstanbul'da dünyaya gelen Koçak, İstanbul Devlet Güzel Sanatlar Akademisinde resim eğitimini 1964 yılında tamamlamış, 1970’te Avrupa'ya gitmiş, dört yıl Paris'te eğitim aldıktan sonra ülkeye dönmüştür. İlk çalışmalarını dışavurumcu bir anlayışla yapan sanatçı zamanla hiperrealist üsluba geçiş yapar. Fetiş Nesneler-Nesne Kadınlar, Mutluluk Resimleriniz, Aile Albümünden, Vitrinler ve Cahide Sonku Portreleri adlı resim serileri bulunmaktadır (Kara, 1998:33-34). Foto Gerçekçilik üslubuyla yaptı̆̆ı kadın konusuna dikkat çeken Pop Sanat eserleriyle tanınmaktadır. Popüler kültüre ait kadının metalaştırmasına dikkat çeken "Fetiş Nesne" serisi ilk dönem resimleri arasındadır. Kadının obje olarak kullanılmasını işleyen sanatçı medya ve dergilerdeki kadının reklam aracı olarak kullanıldığı fotoğraflardan esinlenerek çalışıştır (Muraz, 2009: 40-37). Toplumsal cinsiyet ve Feminizme ilişkin çalışmalar yürüten Koçak kendi çektiği fotoğrafları resmetmektedir. Devasa boyutlarda resmettiği nesnelerle kadın bedeninden daha çok toplumda yalnızca kadınla ilişkilendirilen objeleri eleştirel bir plastik bakış açısıyla betimlemektedir. Eril bakışın karşında yer alan sanatçının çalışmalarında; iç çamaşırı dükkanları, kadın vücudu, makyaj malzemeleri, reklamlarda kullanılan feţ̧̦ ögeler, teşhircilik gibi konuların yanı sıra özlem, sevgi aidiyet duygusu, kimlik, aile ve gelenek gibi unsurları kadın sorununa dikkat çekerek geniş bir yelpazede gözler önüne sermiştir. Sanatçı; kadın sorunun temeline inen cinsiyet ayrımcıllğına dikkat çeken çalışmalarını sürdürmektedir (Otman, 2020: 4043).

\section{Gülsün Karamustafa (1946-...)}

Ankara'da dünyaya gelen sanatçı Devlet Güzel Sanatlar Akademisinden 1966 senesinde mezun olmuştur. Türkiye ve dünyanın çeşitli yerlerinde sergiler açan sanatçının; kitsch, feminizm, göçebelik, göç, arabesk kültür ve popüler kültür gibi konulara yoğunlaşan; resim, video, performans ve enstalasyon gibi farklı türlerde eserleri mevcuttur (Çalışkan, 2019: 100). Sanat macerasına kültürel değerlerini ve kişisel belleğini katan ressam, kültürel bağlarını kendi içinde sanatsal bir dile dönüştürmüştür. Kavram anlatısına ve farklı biçimlemelere odaklanan sanatçı, bütün değerleri sorgulamaya çalışarak yalnızca mevcut olanı değil onun arkasındaki çağrışımı seyirciye yansıtmıştır (Kıyar, Kul, 2019: 789-790). Hedefi, içinde bulunduğu dönemin hızlı değişim ruhunu aktarmak olan sanatçı, yapıtlanında yorumu seyirciye bırakarak objektif kalmaya ihtimam göstermektedir (Çelebi Erol, 2019: 236). Kırdan kentte göçün oluşturduğu, birçoklar1 tarafindan yoz ve arabesk olgusu üzerinden aşağılan kültürel çelişkiyi resimlerinde işlemiştir. Bu durum popülarite kazanmasına, arabesk ressam olarak nitelendirilmesine sebebiyet verir. Göç ve kimlik gibi çalışmalarının temelini oluşturan olguları resimler yaparak anlatmaya başlayan sanatçı zamanla video gibi farklı tekniklere yönelmiştir. Eserlerinin bir kısmında siyasi göndermeler olan Karamustafa, Türkiye'nin yakın tarihine sşık tutmaktadır (Sarığlu, 2007: 7-8).

\section{Sonuç}

Sonuç olarak görmekteyiz ki ideal kadın imgesi tarihin her döneminde farklılaşmış ve zamanla değişime uğraşmıştır. Lakin çoğu zaman kadın anne, eş, kız kardeş, hizmetçi, tanrıça ve nesne olarak erkeğin yansıttığı kadarıyla sanatta yer bulabilmiştir. Farklı kültür, din, etnik köken ve gruplarda; toplumun ve erkeğin idealleştirdiği kalıplara sıkışmıştır. Ancak Feminizm 'in doğuşuyla varlığını haykırabilmiş, yavaş yavaş ve sancılı da olsa dahi günümüzde var olan kadın imgesini oluşturabilmiştir. Yani kadını bütün sıfatları ve görevleri dışında bırakarak kadın kimliğiyle var olması gerektiğini kabul eden düşünceye ulaşılabilmiştir. 
Köse, Z., \& Şahan, G. (2021). Geçmişten günümüze resim sanatında kadına bakış: Sanatta kadın imgesi ve kadın ressamlar. Journal of Human Sciences, 18(3), 431-449. doi:10.14687/jhs.v18i3.6151

Kadınların sanat eğitimi almak gibi temel haklarını elde etmeleri ise yüzyıllar almıştır. İlk süreçlerde sadece zengin ve sanat birikimi olan ailelerin kızları eğitim alabilmiş, uzun süreler kadınlar akademilere kabul edilmemiştir. Bu durumun yanı sıra kadın ressamların yaptığ çalışmalar önemsenmemiş, baba, eş veya başka bir erkek sanatçıya atfedilmiş, ölümlerinden sonra eserleri kaybolmuş, hayatlarına dair tarihe notlar tutulmamıs silinip gitmeye mahkûm edilmiştir. Tarih boyunca yaşanan tüm bu güçlüklere rağmen bugün başarısıyla kendini ispatlamış birçok kadın ressam bulunmaktadır. Zamanla dünyada yaşanan değişimler, eğitime ulaşılabilirliği de nispeten kolaylaştı̆̆ için daha nice kadın ressamın yetişeceği öngörülebilir bir gerçektir.

Sanatçının kitleleri harekete geçirebileceği, toplumsal yaşamda değişim ve dönüşümler oluşturabileceğini söylemek yanlış olmayacaktır. Sanatçının bu gücü doğru yönde kanalize etmesi toplumun bakış açısını etkileyecektir. Bütün bu sebepler göz önünde bulundurulduğunda gelecek nesillere ilham vermek ve dünyayı şekillendirmek adına kadın sanatçllara büyük görevlerin düştüğü söylenebilir. Kadın sanatçıların tam da bu noktada kendilerini ifade etmekten kaçınmamaları, cinsiyetçi zihniyete dur demeleri, ötekileştirmeye ve ayrımcllğa izin vermemeleri için sanatı bir amaç ve araç olarak kullanabileceklerini söylemek gerekmektedir.

\section{Kaynakça}

Akalın, T. \& Baş, R . (2018). Toplumsal cinsiyet eşitsizliğinin kadın sanatçılara yansıması . Marmara Üniversitesi Kadin ve Toplumsal Cinsiyet Araștirmalarn Dergisi , 2 (2) , 112-128

Akçaoğlu, Z. (2010). Bir kadın sanatçı Şükriye Dikmen, Uluslararası Sosyal Araştırmalar Dergisi, 3 (11), $22-26$

Akçay, S. (2015). Türk resim sanatında (1908-1930) Erken Cumburiyet Dönemine kadar ilk ve öncü kadnn ressamlar [Yayınlanmamış yüksek lisans tezi]. Doğuş Üniversitesi, İstanbul

Akkan, A. (2014). Şiddetin plastik yüræü [Yayınlanmamış yüksek lisans tezi]. Hacettepe Üniversitesi, Ankara

Akkaya Kia, R. (2015). Atina'daki demokrasiden Orta Çağ’a kadının dünyası ve filozoflar. Journal of Istanbul University Law Faculty, 73 (1) , 7-20

Aktan, G. (2015). Resim sanatında kadin figürü betimlemeleri [Yayımlanmamış doktora tezi]. Anadolu Üniversitesi, Eskişehir

Albayrak, A. (2012). Saville, Freud, Bacon ve Tuymans'ın paletindeki çileli beden teorisi. Sanat Dergisi, 20, 1-12

Ayan, M . (2008). Weimar dönemi kadın devrimci ruhu ile Kathe Kollwitz . Sanat ve Tasarm Dergisi, $1(1), 33-63$

Aydın, K. \& Karakelle, A. (2019). Modern sanat sürecinde kadın imgesinin resimsel ve toplumsal açıdan incelenmesi. Uluslararası Sosyal Araștırmalar Dergisi, 12 (66), 475-487

Azertürk, S. İ., Akman, T. (2018). Konfüçyüs’ün kadın görüşü üzerine. Eskişehir Osmangazi Üniversitesi Sosyal Bilimler Dergisi, 19 (1), 19-37

Babila, M . (2016). Eski Mısır'da kadın . Kahramanmaraş Sütçü Imam Üniversitesi Sosyal Bilimler Dergisi, $13(1), 130-143$

Bayav, D. (2009). Resim sanatında ve sanat eğitiminde imge. Trakya Üniversitesi Sosyal Bilimler Dergis, $11(2), 105-122$

Bayav, D. (2011). 19.yy. Sonu ve 20. yy. başında kadın ressamlarımız. Dumlupınar Üniversitesi Sosyal Bilimler Dergisi, 29, 15-28

Büyüköztürk, Ş., Kılıç Çakmak, E., Akgün, Ö. E., Karadeniz, Ş. ve Demirel, F. (2021). Bilimsel araștırma yöntemi (30. Baskı). Ankara: Pegem Yayınları

Can, A . (2019). 19. yüzyılda kadın sanatçı olmak: Rosa Bonheur . Tykhe Sanat ve Tasarmm Dergisi , 4 (6) , 386-407

Çalışkan, S . (2019). Gülsün Karamustafa'nın eserlerinde köyden kente göç ve kimlik olgusu . Kirklareli Üniversitesi Sosyal Bilimler Dergisi , 3 (2) , 97-106 
Köse, Z., \& Şahan, G. (2021). Geçmişten günümüze resim sanatında kadına bakış: Sanatta kadın imgesi ve kadın ressamlar. Journal of Human Sciences, 18(3), 431-449. doi:10.14687/jhs.v18i3.6151

Çelebi Erol, C . (2019). İkonografi ve ikonoloji yöntemine göre Gülsün Karamustafa’nın “Örtülü Medeniyet" Ve Kapıc1 Dairesi" adlı eserlerinin analizi . Journal of Institute of Economic Development and Social Researches, 5 (18) , 234-239

Çelebi Kalpak, F. (2019). Çăgdaş resim sanatında kadın bedenin kullanım ve günümür resim sanatına yansımalar [Yayınlanmamış yüksek lisans tezi]. Sakarya Üniversitesi, Sakarya

Çokatak, D. (2014). Frida Kablo'nun resminde kadın olgusu[Yayınlanmamış yüksek lisans tezi]. Trakya Üniversitesi, Edirne

Dağ, H. (2019). Resim sanatında popüler kültür getirilerinin kadın bedeni üz̨erinde temsili [Yayımlanmamıs yüksek lisans tezi]. Akdeniz Üniversitesi, Antalya

Dastarlı, E. (2019). Batıllıaşan Türk resminde kadın imgesinin kamusal alanın oluşumundaki önemi. Yedi: Sanat Tasarm ve Bilim Dergisi, (22), 69-80

Demir, H. (2012). Biz Frida'yı çok sevdik. Kadın Arastırmalar Dergisi, 0 (3), 36-51

Demirel, M . R. (2016). Käthe Kollwitz'in "Tutuklular" adlı eserinin analizi . Yıldız Journal of Art and Design, 3 (2) , 139-152

Demirtaş Ercan, B. (2019). Feminist sanat hareketi ve Filistinli kadın sanaţ̦lar [Yayınlanmamış yüksek lisans tezi]. Batman Üniversitesi, Batman

Dilmaç, O. (2011). Türkiye ve Avrupa'da kadınların sanat eğitiminin karşılaştırmalı tarihçesi . Marmara University Atatürk Education Faculty Journal of Educational Sciences, 34 (34), 99-115

Dönmez Aydın, H. (2016). Kadına biçilen role karşı bir direnme yolu olarak feminist sanat. Yasama Dergisi, (33), 29-49

Duran, A. (2018). Barok dönemde bir kadın ressam: Artemisia Gentileschi [Yayımlanmamıs yüksek lisans tezi]. Atatürk Üniversitesi, Erzurum

Durmuşoğlu, Ö. (2004). Painting and the pornographic: Marlene Dumas, Jenny Saville and plays of identifications [Yayınlanmamış yüksek lisans tezi]. Sabancı Üniversitesi, İstanbul

Ergönül, E. \& Koca, B. (2017). Erken Cumhuriyet Dönemi resimlerinde kadın imgesi: Modernleşme ve milliyetçilik. Art-e Sanat Dergisi, 10 (20) , 761-786

Erişti, Ö. (2015). Geç Dönem Osmanlı resim sanatında kadın imgesinin temsili. Moment Dergi, 2 (2) , 59-79

Eroğlu, G. (2017). Cumburiyet dönemi kadın haklar ışı̆̆gnda öncü Türk kadın ressamlar [Yayınlanmamış yüksek lisans tezi]. Doğuş Üniversitesi, İstanbul

Fırınc1, M. (2006). Toplumsal mücadelede sanatçı duruşuyla Kathe Kollwitz ve "The End" (Son) adlı eserinin analizi . Dokuz Eylül Üniversitesi Buca Eğitim Fakültesi Dergisi , (20), 145-150

Ghorbanzadeh Dizaji, P. (2013). Kültür öznesi olarak kadin resimsel yorumu [Yayınlanmamıs yüksek lisans tezi]. Hacettepe Üniversitesi, Ankara

Gücer, S. (2020). Dişil imge olarak kadın [Yayınlanmamış yüksek lisans tezi]. Hacettepe Üniversitesi, Ankara

Gülaçtı, N. (2012). Sanatsal bir obje olarak kadın ve bazı toplumlarda kadına bakış. İdil Dergisi. 1 (2), 76-91

Gültekin, T. (2013). Sanat eserlerinde kullanılan kadın teması: farklı sanat dönemler üzerinde bir araştırma. Uluslararası Hakemli Sosyal Bilimler E-Dergisi, (34), 1-17

Gümüşer, T. (2013). Osmanlı minyatür sanatında kadın imgelemi. Uluslararası Hakemli Beşerî ve Akademik Bilimler Dergisi: Gǚ Dönemi, 6 (2) 16-28

Güray, E. (2020). Fahrelnissa Zeid'e 1ş1k, renk ve şeffaflık bağlamında yeniden bir bakıss: Paleokrystal serisi ve vitrayları. Kocaeli Üniversitesi Güzel sanatlar Fakültesi Dergisi. 8 (8) , 4656

Güzel, B. (2015). Lysıstrata: kadının antik Yunan toplumundaki yeri. International Periodical for the Languages, Literature and History of Turkish or Turkic, 10 (10),505-522

Halman, T. S. (2011). Kutlu Narsist: Fahr El Nissa Zeid. Ürün Yaymlar, 23, 133-141. http://hdl.handle.net/11693/54479

Işıkören, N . D. (2015). Kadın imgesi ve tarih boyu değişimi . Sanat ve Tasarm Dergisi , 0 (16) , 115 131 
Köse, Z., \& Şahan, G. (2021). Geçmişten günümüze resim sanatında kadına bakış: Sanatta kadın imgesi ve kadın ressamlar. Journal of Human Sciences, 18(3), 431-449. doi:10.14687/jhs.v18i3.6151

İbrahimgil, M. Z. (2015). Orta Öğretim Sanat Tarihi Ders Kitabı, Koza Yayıncılık, Ankara

İldeş, G. (1996). Modern resimde kompozisyonlarda kaden figürü ve form iliskisi [Yayınlanmamıs yüksek lisans tezi]. Marmara Üniversitesi. İstanbul

İz, Y. (2006). Neş'e Erdok resminde konu, biçim ve içerike(anlam) açısından gerçeklik olgusu[Yayınlanmamış yüksek lisans tezi]. Mersin Üniversitesi, Mersin

Kaplanoğlu, S. (2006). Çin'de kadin imgesi [Yayınlanmamış yüksek lisans tezi]. Ankara Üniversitesi, Ankara

Kaptan, C. (2013). Ac1 ve sanat. Sanat ve tasarm dergisi, 1 (12), 59-81

Kara, H. (1998). Günümür Türk kadn ressamlarndan bir kesit [Yayımlanmamış yüksek lisans tezi]. İstanbul Teknik Üniversitesi, İstanbul

Karaaslan, D. (2016). Antik Yunan'da kadın olmak. Sürt Üniversitesi İlabiyat Fakültesi Dergisi, 1(2), 159-174

Karabaş Avşar, P. (2016). Çağdaş Türk resim sanatında Şükriye Dikmen'in yeri ve önemi. İdil Dergisi, 5(19), 267-291

Karaca, R. (2015, 1 Mart). Kadınm çağlar boyunca toplumdaki yeri. İnformedika. Erişim tarihi: 2 Şubat 2021, ～http://informadik.blogspot.com/2015/07/kadnn-caglar-boyunca-toplumdakiveri.html

Karasar, N. (2016). Bilimsel araştırma yöntemi: Kavramlar, ilkeler ve teknikler (30. baskı) Nobel Akademi Yayinc1lik

Kathleen, H. (2018). Concubine or cougar? Constructing the creative female persona in Early Modern Europe, and transitioning from indirect power toward direct power in a man's world, Forum on Public Policy Online, 0(1), 1-14

Kaya Okan, B. (2011). Arkaik sembolizmin günümüz sanatına etkileri ve kadın imgesi. İönü Üniversitesi Sanat ve Tasarm Dergisi. Özel Sayı, 1, 2-6

Kaynar Tanır, A. (2019). Käthe Kollwıtz'in "Yoksulluk" adlı yapıtının çözümlenmesi. Uluslararası Sanat Kültür ve İletisim Dergisi , 2 (1) , 1-17

Kesenci, M. (2020). Rönesans döneminde dört kadın ressam: Levina Teerlinc, Catherina Van Hemessen, Sofonisba Anguissola ve Lavinia Fontana. Social Sciences Research Journal, 9 (3), 31 48.

Keser, N. (2013). Akademiler çağının ötekileri: kadın ressamlar. Kafkas Üniversitesi Sosyal Bilimler Enstitü Dergisi , 1 (11), 77-84

Kıyar, N. \& Kul S. (2019). "Sanat tanımı topluluğu ve bağımsız bir çağdaş: Gülsün Karamustafa" İdil Dergisi, 58, 783-791

Krom I. (2010). Sanat/cinsiyet: sanat tarihi ve feminist eleştiri .International Journal of Social Science, 29 , 125-137 http://dx.doi.org/10.9761/JASSS2551

Kurşunlu, N. (2019). Căğdaș İngili figüratif resminde duyumsanan beden: Francis Bacon, Jenyy Saville, Lucien Freud [Yayımlanmamış yüksek lisans tezi]. Dokuz Eylül Üniversitesi, İzmir

Küçükşen Öner, F . (2017). Türk resminin ve toplum hayatının değişim göstergesi olarak kadın. Sanat ve Tasarm Dergisi, 19, 103-121

Küçükyıldız, N. (2020). Sanat Taribi 1. Millî Eğitim Bakanlığı Hayat Boyu Öğrenme Genel Müdürlüğü Açı Öğretim Daire Başkanlığ1

Mavioğlu, G. \& Karbeyaz K. (2017) Kadına yönelik ayrımcı filler açısından ressam Artemisia Gentileschi, Osmangazi T⿰力 Dergisi, 39(3) 140-145 Doi: 10.20515/otd.321475

Menteşoğlu Chatzoudas, Ç. \& Günaydın, Ş . (2020). Toplumsal Gerçekçilik hareketi içinde kadın bir sanatçı olarak Neş'e Erdok . Avrasya Uluslararası Araștırmalar Dergisi , Avrasya Uluslararası Araştırmalar Dergisi Özel Say1 , 383-398 . DOI: 10.33692

Muraz, Ö. (2009). Nur Koģak'in pop sanat, foto-gerçekçilik, feminist sanat ve posta sanatı içinde incelenmesi [Yayımlanmamış yüksek lisans tezi]. Çukurova Üniversitesi, Adana

Otman, S. (2020). 1960 sonrast çağdas sanatta toplumsal cinsiyet bağlammda feminizm: Judy Chicago ve Nur koşak karşılaştırması [Yayımlanmamış yüksek lisans tezi]. Akdeniz Üniversitesi, Antalya 
Köse, Z., \& Şahan, G. (2021). Geçmişten günümüze resim sanatında kadına bakış: Sanatta kadın imgesi ve kadın ressamlar. Journal of Human Sciences, 18(3), 431-449. doi:10.14687/jhs.v18i3.6151

Özbay Aydoğan, S. M. (2006). Kadın bedeni kurgular ve teslimiyet: 1970 batı sanatmda bedenlerini kullanan kadinlar [Yayınlanmamış yüksek lisans tezi]. Yıldız Teknik Üniversitesi, İstanbul

Özensoy, E. (2017). Modern sanatm doğusunda kadın imgesi: Türk ve Avrupa resim sanatı karşlaştırması [Yayınlanmamış yüksek lisans tezi]. İstanbul Teknik Üniversitesi, İstanbul

Parten Altuncu, A . (2020). Çağdaş Sanatta Kadın Temsilinin İmgesi: Saç, Gǚel Sanatlar Enstitüsü Dergisi, 26 (44) , 104-116

Przybylek, S. (2021). Levina Teerlinc: Biography and works. Study.com. Erişim tarihi: 16 Şubat 2021, https://study.com/academy/lesson/levina-teerlinc-biography-works.html

Renkçi, T. (2014). Çağdaş bedenin sanatçısı: Jenny Saville. Akdeniz Sanat, 7 (13), 137-147

Sağlam, N. (2000). Kadın ressamlar: Orta çağdan günümų̈̌e. [Yayınlanmamış yüksek lisans tezi]. Mimar Sinan Üniversitesi, İstanbul

Salas, J. M. G. (2019). Artemisia Gentileschi: Drama, revenge and Feminism in her work. Asparkía Investigación Feminista, 34, 109-133

Sarıoğlu, S. (2007). Gülsün Karamustafa: sanatçı kişiliği ve yapıtlan [Yayınlanmamış yüksek lisans tezi]. Mimar Sinan Üniversitesi, İstanbul

Satır, M. (2012). Resimde kadin imgesi [Yayımlanmamış doktora tezi] Atatürk Üniversitesi, Erzurum

Söğütlü Erişgin, Ö. (2016). Roma toplumunda kadının konumu. İnönü Üniversitesi Hukuk Fakültesi Dergisi, 4 (2), 1-31

Sözer Sarac, Y. (2011).İslam halklarının sanat anlatım yöntemleri: "minyatür". İslam Arasturmalar Dergisi, 4 (1), 171-194

Sürücü, M. (2011). Türk resim sanatında kadn ressamlarn üzerinden kadmn imgesinin incelenmesi [Yayınlanmamış yüksek lisans tezi]. Mimar Sinan Üniversitesi, İstanbul

Şahin, M. (2014). Cağdaş Türk resminde kadin imgesi (1960-1980) [Yayınlanmamış yüksek lisans tezi]. Gazi Üniversitesi, Ankara

Şahinbaş, U., Türker, İ. \& Ağçiçek, M . (2019). Savaşlar ve ölümler çağında bir kadın sanatçı: Kathe Kollwitz . Akademik Sanat , 4 (8), 160-171

Şahmaran Can, G. (2016). Tanzimat'tan cumhuriyet dönemi Türkiye'sine öne çıkan kadın sanatçılar. Idil Dergisi, 5 (23), 1017-1036

Şen, E. \& Gürpınar, F. (2019). Türk resim sanatında kadın imgesi. Ulakbilge, 42, 875-891. Doi: 10.7816/Ulakbilge-07-42-10

Şentürk, H. (2018). Siyah ve Gri"nin kullanilssinda iki farkl yorum (Adnan Coker/ Neş'e Erdok)(Yayınlanmamış yüksek lisans tezi]. Mimar Sinan Güzel Sanatlar Üniversitesi, İstanbul

Tiryaki, K. (2019). İbrabim Çall, Neş'e Erdok, Turgut Zaim Türk sanatına katkular ve eserlerinin konu, biçim, içerik açısından incelenmesi [Yayınlanmamış yüksek lisans tezi]. Giresun Üniversitesi, Giresun

Uçar, S. (2020). Kadın düşün dünyasında Türk modernleşmesi ve kadın imgesi [Yayınlanmamış yüksek lisans tezi]. Ankara Üniversitesi, Ankara

Uyar, S. (2016). Kadın ressamlarn eserlerinde acı kavrammm analitik bir çözümlemesi. [Yayınlanmamış yüksek lisans tezi]. Kemerburgaz Üniversitesi, İstanbul

Yanar, S. (2010). Günümüz Resim sanatında kadın figürüne bakıı̧s [Yayınlanmamış yüksek lisans tezi]. Mimar Sinan Üniversitesi, İstanbul

Yazgin, Y. (2019). Kuzey Kibris'ta kadın ressamların resimlerinde kadın imgesi, Manas Sosyal Arastrmalar Dergisi, 8(1), 185-200

Yıldırım, G. (2010). Devrimin kırlangıç kaşlı asi kadını Frida. Divriği Kültür Sanat Dergisi, 3, 7-10

Yilmaz, A. (2011). 1950 Sonrası Türk resim sanatinda sosyal yansimalar bağlaminda Neş'e Erdok [Yayınlanmamış yüksek lisans tezi]. Süleyman Demirel Üniversitesi, Isparta

Yılmaz, C . (2020). Hatşepsut: Naibelikten firavunluğa yürüyen bir kraliçe . OANNES - Uluslararası Eskiçă̆ Taribi Araștormalar Dergisi , 2 (2) , 277-300 
Köse, Z., \& Şahan, G. (2021). Geçmișten günümüze resim sanatında kadına bakıș: Sanatta kadın imgesi ve kadın ressamlar. Journal of Human Sciences, 18(3), 431-449. doi:10.14687/jhs.v18i3.6151

\section{Extended English Summary}

Throughout the history of the world, the woman has been treated as a secondary human under the influence of the patriarchal order and is stuck in the positions assigned by the society, such as a mother, wife, lover, inspirational and sexual object. The woman has existed for centuries as much as the man reflects on the canvas, and could not go beyond being portrayed following the ideal woman's understanding of the period. Everything that is expected from women, desired and described as a duty is almost reinforced with the art of painting

Artworks and artists reflect the perspective of the lifestyle of the period, are influenced by society, and at the same time affect society. The main purpose of this article, which explores the image of women in art, is to examine the existing process of women in art. In this context from the first centuries to the present process of change and artistic reflection of the image of women in the history of Turkey and the world has been described.

The process of women's existence in art goes back to the Paleolithic age. The woman we come across in cave paintings and Venus figurines; was seen as a goddess with the influence of the matriarchal order, her fertility added a mystery to her, she was blessed for taking active roles in social life and ensuring the continuation of the lineage. With the transition to power-based agriculture, the woman was imprisoned in the home, the domination of the man began, and she assumed the identity of a mother and wife, whom she could not escape for centuries. This situation started to manifest itself with the increase in the statuettes named Phallus, which glorify men in the field of art. The active presence of women in art life has gradually faded with the transition to the patriarchal order.

Although there is a caste system in Ancient Egypt, one of the most important civilizations in world history, it is possible to say that women have more rights and freedoms compared to their contemporaries. When we look at the history of Egypt, there have been women such as Hatshepsut, Nefertiti, VII. Cleopatra who played an active role in the government known today. Women were depicted or sculpted side by side with their spouses in artworks, women were allowed to be in high positions, women's rights were enacted. But in Ancient Greece, this situation appears as a deep misogyny. Perfect beauty and body are desired, the image of woman has found a place in art with mythological elements.

In ancient Rome, the virginity of the woman was idealized, her chastity was questioned before the society, and she was deprived of fundamental rights and freedoms. With the spread of Christianity, artworks were allowed to be depicted with only religious figures by covering the female body. In the Middle Ages, the persecution of women was considered normal and the woman was considered a demonic being. In addition, women in the noble class were treated separately. Woman was seen as a helpless, sinful and fragile creature in need of the protection of men. The artworks taken under the control of the church were used for the purpose of spreading religion, and the female figure was identified with the Virgin Mary.

When it came to the Renaissance, women were also affected by the innovation movements and women who were engaged in the art of painting began to show their existence, even if they were not educated by their fathers and accepted to the academies. Despite this, they were portrayed by many painters, highlighting the nudity and beauty of the woman. The influence of religion and the church continued in later processes, and the process of proving the existence of women could only begin with the French revolution. Women seeking their rights and freedoms began to make their voices heard, and the female figure simplified and moved away from exaggerated images. With the industrial revolution, women's participation in working life has also changed the position of women in social life and strengthened the pursuit of rights of women who became independent. Feminism has shouted to the whole world that a woman is an individual. Art movements continued to support this situation, feminism found a place in art and pioneered the change in the view of women. With the birth of contemporary art and the woman painting herself, the image of women 
Köse, Z., \& Şahan, G. (2021). Geçmişten günümüze resim sanatında kadına bakış: Sanatta kadın imgesi ve kadın ressamlar. Journal of Human Sciences, 18(3), 431-449. doi:10.14687/jhs.v18i3.6151

in art has begun to change. It has enabled the formation of an understanding of art in which the inner world of women cares and is reflected with a female identity.

When the transformation of the image of women in Turkey in art history; It can be said that in the Turks, who are a nomadic society, artworks started to become widespread only with the transition to settled life. With the acceptance of Islam by the Turks, the art of painting was not welcomed for religious reasons. It has been possible to encounter the female figure only in miniature art. Miniature, which lived its golden age in the Ottoman period, was generally made for the dynasty, and the female figure was generally depicted in interior spaces such as homes, baths, gardens. The painting of men and women side by side took place in the following processes, and with the influence of western art, the female figure began to be drawn more clearly over time. The westernization process has also caused the transition from miniature to painting. In the first period, women were depicted in veiled, closed clothes and closed spaces, but over time, they became a symbol of modernization, stripped of the perception of privacy, and their position and stance were changed. In the last period of the Ottoman Empire, the first steps were taken to educate women painters by opening the Inas Sanayi-i Nefise School, which gave education to women.

With the foundation of the Republic, women found a place in the public sphere, were seen as a symbol of innovation, and gained their rights and freedoms. Making the public adoption of the new image of women became a state policy and the art of painting was used as a suitable tool for this purpose. Painters were sent to study abroad, art schools were opened, painters were sent to various parts of Anatolia and the new regime was explained to the public through art. Women painters also found a place in the field of art and received state-sponsored education.

The war of women with the patriarchal order, traditional perspective and being seen as a sexual object has continued until today. This situation has also influenced Turkish painting art and the view of the female body has turned into an individualized situation that the artist reflects in parallel with the perception of women. Today, many Turkish female and male painters continue to work to change the social position of women and the image of women in memories and to ensure their existence as an individual.

The admission of women to art academies took place at the end of the 19th century. However, despite the difficulties until this period, many female painters have been trained. In this article, some of the talented and successful female painters who try to exist in the field of art despite many difficulties and who have enabled women to become effective in the art are discussed. One of them is Levina Teerlinc, the first woman painter in history. Although the artist was successful throughout her life, her work was not given importance and protected. Little information about the artist was kept by her father. One of them is Levina Teerlinc, the first woman painter in history. Although the artist was successful throughout her life, her work was not appreciated and protected. Little information about the artist was kept by her father. Artemisia Gentileschi, who depicts women as powerful, energetic and confident in her works, has been the trigger of feminism in art by successfully reflecting this situation, which she could not get out of, even though she was engraved in memories with the traumatic rape. Rosa Bonheur defended the equality of men and women and was one of the initiators of women's struggle in art. The painter Käthe Kollwitz has fought for the rights of workers and women all her life. Frida Kahlo, on the other hand, made her name known to the whole world during and after her life with her art, and despite her painful life story, she set an example for many women and painters with her dauntless attitude. Jenny Saville used her art as the greatest criticism tool to destroy bad perceptions about the female body.

One of the first Turkish woman painters, Mihri Müşfik Hanım pioneered many women with her character, lifestyle, paintings and pieces of training by displaying a perspective ahead of her time. Fahrelnisa Zeid exhibited her paintings in many countries and introduced her successful works and Turkish women to the world. Şükriye Dikmen, on the other hand, managed to exist in the art community with her unique style and female figures with her contemporary painting approach. Neşe Erdok, reflecting the woman as an individual, did not hesitate to explain social problems and managed to leave her mark with her melancholy style. Nur Koçak, whose feminist 
Köse, Z., \& Şahan, G. (2021). Geçmişten günümüze resim sanatında kadına bakış: Sanatta kadın imgesi ve kadın ressamlar. Journal of Human Sciences, 18(3), 431-449. doi:10.14687/jhs.v18i3.6151

identity also takes place in her art, has succeeded in making her name known in the sense of pop art with her hyperrealist works. Gülsün Karamustafa has proven herself in the art community with her works on various themes such as migration, kitsch, feminism and popular culture.

As a result, the image of the ideal woman has tried to change in every period of history, but often as a mother, wife, sister, servant, goddess and object, it has found a place in art as much as the man reflects. In different cultures, religions, ethnic origins and groups; it is stuck in the patterns idealized by society and man. However, with the birth of feminism, she was able to cry out her existence and create the image of the woman that exists today, even if it is slow and painful. In other words, the idea that accepts that women should exist as a woman by excluding all their attributes and duties has been attained.

It took centuries for women to acquire their basic rights such as education, so they were not accepted into academies for a long time. The works of women painters were disregarded, attributed to their father or their wives, their works disappeared after their deaths, no historical notes were made about their lives, and they were condemned to be erased. Despite everything, there are many female painters who have proven themselves successfully today. Art, self-expression is some of the best ways to support a woman's existence as a woman. We believe that women will not abandon their combative attitude and continue to exist in art with their own hands, not as reflected by someone else ... 